Brit. Heart J., 1965, 27, 319.

\title{
THE PULMONARY CAPILLARY BED IN MITRAL VALVE DISEASE
}

\author{
BY \\ JOHN HAMER \\ From The Institute of Cardiology and The National Heart Hospital, London W.1
}

Received August 16, 1964

Disturbances in the exchange of gases between the alveolar air and the blood in the pulmonary capillaries can be used to estimate the effects of disease on the pulmonary capillary bed. These techniques have been applied to the investigation of the effects of sustained elevation of the pulmonary venous pressure in mitral valve disease.

Carbon monoxide is used as a test substance to assess abnormalities in gas absorption as it behaves in the same way as oxygen, combining avidly with the hæmoglobin in the pulmonary capillary red cells. Measurement of the factors affecting carbon monoxide uptake is much simpler than in the case of oxygen. The rate of absorption of these gases, expressed in relation to the difference in partial pressure of the gas between the alveoli and the capillaries (i.e. in $\mathrm{ml} . / \mathrm{mm}$. $\mathrm{Hg} / \mathrm{min}$.), has usually been described as the "diffusing capacity" $\left(D_{L}\right)$ on the hypothesis that diffusion was the only process involved. However, it has been shown (Roughton and Forster, 1957) that the chemical reaction between the respiratory gases and hæmoglobin is relatively slow and accounts for much of the resistance to absorption of these gases. In view of this, Cotes (1963) has suggested the non-committal term "gas transfer factor" to describe these measurements.

The competition between carbon monoxide and oxygen for the available hæmoglobin can be used to separate that part of gas transfer taking place in the red cells. If the rate of the chemical reaction $(\theta)$ and the hæmatocrit are known the volume of the pulmonary capillaries (Vc) can be calculated. The remaining component of gas transfer gives an estimate of the movement of gas across the alveolar-capillary membrane $\left(D_{M}\right)$ (Fig. 1).

Reports of the histological changes in the lungs in mitral valve disease suggest that the capillary volume is increased and the alveolar wall thickened, and it has been suggested that these changes may play a part in reducing the arterial oxygen saturation. In the present work the capillary volume $(\mathrm{Vc})$ and the membrane component $\left(D_{M}\right)$ have been measured to evaluate the functional significance of the pulmonary changes.

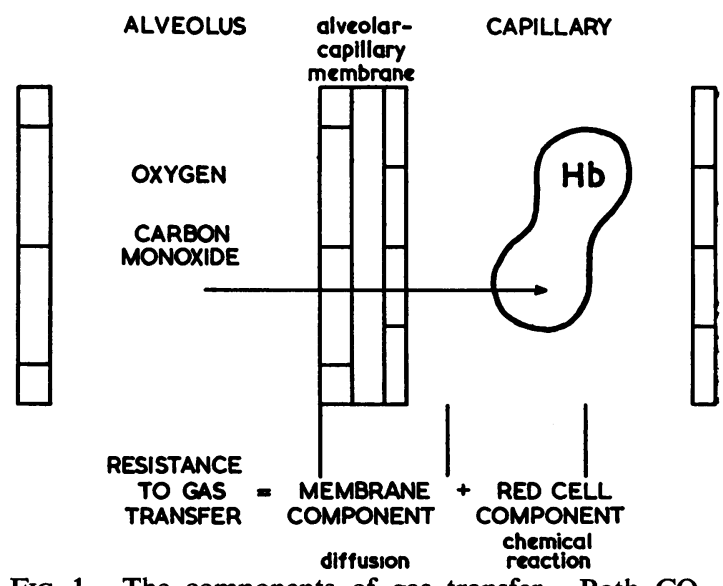

FIG. 1.- The components of gas transfer. Both $\mathrm{CO}$ and $\mathrm{O}_{2}$ pass through the alveolar-capillary membrane by diffusion and combine with the hæmoglobin in the pulmonary red cells. The rate of the chemical reaction in the red cell is relatively slow and is responsible for a considerable proportion of the resistance to $\mathrm{CO}$ and $\mathrm{O}_{2}$ transfer. (By permission of the editor of Thorax (1964), 19, 507.) 


\section{SUBJECTS AND METHODS}

Forty patients with mitral valve disease were studied (Table I). The diagnosis was confirmed by operation in 23 and by cardiac catheterization in 21 patients. In 6 the diagnosis was based on clinical criteria alone. Breathlessness of sufficient severity to interfere with normal activities had been present for an average of $5 \cdot 25$ years. In 21 patients there had been a recent episode of pulmonary congestion; in 8 this was associated with the onset of uncontrolled atrial fibrillation. Patients were not studied until they had received satisfactory treatment for pulmonary congestion. Atrial fibrillation was present in 28 at the time of study, 12 patients gave a story of repeated episodes of bronchitis, and 10 were habitual smokers.

The patients are classified in four main groups (Table I):

Group 1: serious mitral stenosis requiring operation (17).

Group 2: serious mitral stenosis with moderate mitral incompetence (12).

Group 3: severe mitral incompetence requiring operation (4).

Group 4: mild mitral valve disease not needing operative treatment (7).

There was little difference in the severity and duration of symptoms in the three groups of patients judged to have serious lesions. Those with mild mitral valve disease tended to be older and to have relatively little breathlessness.

The methods used were similar to those employed to measure the components of gas transfer in normal subjects (Hamer, 1962) and in patients with diffuse lung disease (Hamer, 1963a, 1964). The single breath technique described by Ogilvie et al. (1957) was used, with some modifications, to measure the carbon monoxide uptake at two levels of oxygen tension in each subject. After a full but unforced expiration a maximal breath of gas containing approximately 0.2 per cent $C O$ and either 5 per cent or 15 per cent helium was inspired and held for about 10 seconds. Two gas mixtures were used, one made up in pure $\mathrm{O}_{2}$ and the other with 20 per cent $\mathrm{O}_{2}$ and the remainder $\mathrm{N}_{2}$ (referred to as the "air" mixture). Straining during breathholding was avoided as much as possible. A single three-way tap was used to reduce the dead space of the apparatus. Rubber bags were applied to the outlet of the tap using tapered airtight connectors and were then evacuated by a suction line. A sample was collected after the expiration of about $750 \mathrm{ml}$. to flush out the dead space. Unduly forceful expiration was avoided and sampling time kept as small as possible: In general approximately $750 \mathrm{ml}$. of expirate was collected in about half a second.

In patients 1 to 33 part of each sample was transferred to a mercury tonometer for the subsequent measurement of $\mathrm{O}_{2}$ and $\mathrm{CO}_{2}$ content by the Scholander method. In subjects 34 to 40 part of the sample was used to measure $\mathrm{O}_{2}$ and $\mathrm{CO}_{2}$ tension by means of an Instrumentation Laboratory Inc. electrode system. The remainder of the sample was then drawn through a $\mathrm{CO}_{2}$ absorber to the gas analysers. A sample of the gas to be inspired was drawn through the analysers before each estimation. Approximately 0.5 litre of gas was needed for accurate measurement of $\mathrm{CO}$ and $\mathrm{He}$. In patients 1 to 21 the sample passed through a Godart Pulmoanalyser set to read He concentrations up to 5 per cent in moist air; a mixture containing 5 per cent $\mathrm{He}$ was used in these patients and all measurements were made on saturated gas. In subjects 22 to $\mathbf{4 0}$ a Godart Katapherometer with a range up to 15 per cent $\mathrm{He}$ was used; a $\mathrm{CaCl}_{2}$ drying tube was inserted in the line after the $\mathrm{CO}_{2}$ absorber and all measurements were made on dry gas, using a mixture containing 15 per cent $\mathrm{He}$. The flow rate through both $\mathrm{He}$ meters was approximately $200 \mathrm{ml} / \mathrm{min}$. The He readings were corrected for variations in oxygen content on the basis of a reading of 1.2 per cent He with 100 per cent $\mathrm{O}_{2}$, assuming a linear increase in the reading between 21 and 100 per cent $\mathrm{O}_{2}$ in the gas carrying the helium. The sample also passed through an Infra Red Development Co. CO analyser (type SCLA) at a flow rate of $500 \mathrm{ml} . / \mathrm{min}$. This instrument was calibrated before each study with a standard gas mixture supplied by the makers. One scale, extending from 0.03 to 0.25 per cent $\mathrm{CO}$, was used for measurement of both the inspired and expired gas, and the linearity of the response was confirmed by comparison with the catharometer readings, using serial dilutions of mixtures of $\mathrm{CO}$ and $\mathrm{He}$. In patients 1 to 21 a drying tube was placed in the inflow line to the infra red analyser. The $\mathrm{CO}$ and $\mathrm{He}$ contents of the expired sample were corrected for the $\mathrm{CO}_{2}$ absorbed.

The duration of breath-holding and the volume of gas inspired were obtained from the spirometer chart. Breath-holding was measured from the beginning of inspiration to the beginning of sample collection, and the value corrected as suggested by Jones and Meade (1961), i.e. half the sampling time was added and threetenths of the inspiratory time subtracted, to allow for variations in the timing of inspiration and expiration. The effective lung capacity during breath-holding was calculated from the dilution of the inspired He as 
TABLE I

Physical Features

\begin{tabular}{|c|c|c|c|c|c|c|c|}
\hline $\begin{array}{l}\text { Serial } \\
\text { No. }\end{array}$ & $\begin{array}{l}\text { Associated } \\
\text { features }\end{array}$ & $\begin{array}{l}\text { Age } \\
\text { (yr.) }\end{array}$ & Sex & $\begin{array}{l}\text { Height } \\
\text { (in.) }\end{array}$ & $\begin{array}{l}\text { Weight } \\
\text { (lb.) }\end{array}$ & $\begin{array}{l}\text { BSA } \\
\left(\mathrm{m} .{ }^{2}\right)\end{array}$ & $\underset{(\mathrm{g} . / 100 \mathrm{ml} .)}{\mathrm{Hb}}$ \\
\hline \multicolumn{8}{|c|}{ Serious mitral stenosis } \\
\hline $\begin{array}{r}1 \\
2 \\
4 \\
6 \\
8 \\
9 \\
11 \\
12 \\
17 \\
18 \\
20 \\
21 \\
25 \\
33 \\
35 \\
36 \\
40\end{array}$ & $\begin{array}{l}\text { AI } \\
\text { Severe AI } \\
\text { Severe AI } \\
\text { AI } \\
\text { AI, hyp. } \\
\text { AI, TS } \\
\text { AI - } \\
\text { PH - } \\
\text { AI - } \\
\text { - } \\
\text { PH } \\
-\end{array}$ & $\begin{array}{l}47 \\
46 \\
21 \\
53 \\
39 \\
51 \\
22 \\
36 \\
44 \\
46 \\
57 \\
36 \\
32 \\
26 \\
43 \\
38 \\
48\end{array}$ & $\begin{array}{l}M \\
M \\
F \\
F \\
F \\
M \\
F \\
F \\
M \\
F \\
F \\
F \\
F \\
F \\
F \\
F \\
F\end{array}$ & $\begin{array}{l}65 \\
66 \\
68 \\
63 \\
64 \\
66 \\
64 \\
62 \\
72 \\
58 \\
61 \\
63 \\
64 \\
66 \\
63 \\
63 \\
61\end{array}$ & $\begin{array}{l}145 \\
111 \\
128 \\
141 \\
112 \\
156 \\
108 \\
102 \\
172 \\
82 \\
128 \\
110 \\
115 \\
130 \\
105 \\
130 \\
108\end{array}$ & $\begin{array}{l}1.72 \\
1.54 \\
1.36 \\
1.66 \\
1.51 \\
1.78 \\
1.51 \\
1.44 \\
2.00 \\
1.25 \\
1.56 \\
1.50 \\
1.55 \\
1.64 \\
1.47 \\
1.60 \\
1.46\end{array}$ & $\begin{array}{l}16 \cdot 2 \\
13 \cdot 7 \\
13 \cdot 4 \\
13 \cdot 4 \\
13 \cdot 2 \\
14 \cdot 5 \\
13 \cdot 9 \\
15 \cdot 5 \\
15 \cdot 3 \\
14 \cdot 0 \\
13 \cdot 8 \\
13 \cdot 1 \\
13 \cdot 0 \\
15 \cdot 7 \\
15 \cdot 5 \\
13 \cdot 8 \\
17 \cdot 2\end{array}$ \\
\hline \multicolumn{8}{|c|}{ Serious mitral stenosis with moderate incompetence } \\
\hline $\begin{array}{r}3 \\
7 \\
10 \\
14 \\
15 \\
16 \\
19 \\
24 \\
30 \\
34 \\
37 \\
39\end{array}$ & $\begin{array}{l}\text { AI } \\
\text { AI } \\
\text { AI } \\
\text { AI, PH } \\
\text { AI, TS } \\
\text { AI, PH } \\
\text { AI - } \\
\text { AS, AI } \\
\text { AS, AI } \\
\text { AI }\end{array}$ & $\begin{array}{l}46 \\
53 \\
48 \\
50 \\
46 \\
55 \\
59 \\
49 \\
36 \\
44 \\
32 \\
48\end{array}$ & $\begin{array}{l}\mathrm{M} \\
\mathrm{F} \\
\mathrm{M} \\
\mathrm{M} \\
\mathrm{M} \\
\mathrm{F} \\
\mathrm{F} \\
\mathrm{M} \\
\mathrm{F} \\
\mathrm{F} \\
\mathrm{F} \\
\mathrm{F}\end{array}$ & $\begin{array}{l}65 \\
63 \\
72 \\
70 \\
70 \\
63 \\
65 \\
68 \\
62 \\
63 \\
69 \\
64\end{array}$ & $\begin{array}{l}150 \\
130 \\
169 \\
135 \\
148 \\
130 \\
103 \\
142 \\
110 \\
138 \\
123 \\
114\end{array}$ & $\begin{array}{l}1.75 \\
1.60 \\
1.97 \\
1.77 \\
1.85 \\
1.61 \\
1.45 \\
1.75 \\
1.48 \\
1.65 \\
1.74 \\
1.54\end{array}$ & $\begin{array}{l}13 \cdot 4 \\
12 \cdot 1 \\
13 \cdot 4 \\
14 \cdot 4 \\
\overline{14 \cdot} \\
14 \cdot 4 \\
15 \cdot 2 \\
16 \cdot 1 \\
14 \cdot 9 \\
13 \cdot 9 \\
13 \cdot 2\end{array}$ \\
\hline \multicolumn{8}{|c|}{ Severe mitral incompetence } \\
\hline $\begin{array}{r}5 \\
23 \\
26 \\
31\end{array}$ & $\begin{array}{l}\text { AI } \\
\text { TS, PH } \\
\text { AI, PH } \\
\text { Severe AI }\end{array}$ & $\begin{array}{l}48 \\
40 \\
48 \\
25\end{array}$ & $\begin{array}{l}F \\
F \\
F \\
M\end{array}$ & $\begin{array}{l}58 \\
61 \\
59 \\
65\end{array}$ & $\begin{array}{r}100 \\
90 \\
108 \\
109\end{array}$ & $\begin{array}{l}1.43 \\
1.34 \\
1.43 \\
1.53\end{array}$ & $\begin{array}{l}13 \cdot 9 \\
15 \cdot 1 \\
14 \cdot 6 \\
14 \cdot 7\end{array}$ \\
\hline \multicolumn{8}{|c|}{ Mild mitral valve disease } \\
\hline $\begin{array}{l}13 \\
22 \\
27 \\
28 \\
29 \\
32 \\
38\end{array}$ & $\begin{array}{l}\text { AI, CP } \\
\text { AI } \\
\text { hyp. } \\
= \\
\text { AI }\end{array}$ & $\begin{array}{l}60 \\
50 \\
59 \\
58 \\
60 \\
45 \\
34\end{array}$ & $\begin{array}{l}\mathrm{M} \\
\mathrm{F} \\
\mathrm{F} \\
\mathrm{M} \\
\mathrm{M} \\
\mathrm{F} \\
\mathrm{M}\end{array}$ & $\begin{array}{l}68 \\
67 \\
63 \\
68 \\
69 \\
66 \\
68\end{array}$ & $\begin{array}{l}157 \\
125 \\
123 \\
141 \\
154 \\
123 \\
152\end{array}$ & $\begin{array}{l}1.85 \\
1.65 \\
1.57 \\
1.76 \\
1.86 \\
1.64 \\
1.83\end{array}$ & $\begin{array}{l}13 \cdot 7 \\
13 \cdot 1 \\
12 \cdot 6 \\
15 \cdot 6 \\
14 \cdot 6 \\
12 \cdot 8 \\
14 \cdot 7\end{array}$ \\
\hline
\end{tabular}

$\mathrm{AI}=$ aortic incompetence; $\mathrm{TS}=$ tricuspid stenosis $\mathrm{AS}=$ aortic stenosis; $\mathrm{PH}=$ pulmonary vascular resistance $>10$ units $\mathrm{m}_{.2} ; \mathrm{CP}=$ constrictive pericarditis; hyp. $=$ systemic hypertension.

suggested by McGrath and Thomson (1959), after subtraction of an estimated value for the dead space. In normal subjects the effective capacity calculated in this way differs little from the volume obtained by the closed circuit method (McGrath and Thomson, 1959; Hamer, 1962).

The pulmonary capillary carbon monoxide concentration was estimated by equilibration at high oxygen tensions before and after each study. An equilibrated sample was obtained after a preliminary period breathing oxygen by rebreathing for four minutes in a 6-litre closed circuit filled with oxygen and containing a $\mathrm{CO}_{2}$ absorber (Siösteen and Sjöstrand, 1951). Values for each experiment were obtained by interpolation 
and corrected to the appropriate $\mathrm{Po}_{2}$ by direct proportion. The estimated pulmonary capillary $\mathrm{CO}$ concentration was subtracted from both the initial and final alveolar $\mathrm{CO}$ concentrations before calculation of the diffusing capacity. A small further correction was made to the initial concentration for the $\mathrm{CO}$ in the residual volume before each experiment.

The rate of uptake of $\mathrm{CO}$ by the blood $(\theta)$ was calculated for each experiment from the relation $\frac{1}{\theta}=0.33$ $+0.0057 \mathrm{Po}_{2}$ obtained from Fig. 1 of Roughton and Forster (1957) for $\lambda=\infty$, i.e. on the assumption that there is no increase in the resistance to gas transfer at the red cell surface. Recent work shows no evidence of such a resistance in vivo (Thews and Niesel, 1959; Kreuzer and Yahr, 1960; Sirs, 1963). The appropriate $\mathrm{Po}_{2}$ was obtained as suggested by $\mathrm{McNeill}$, Rankin, and Forster (1958) by adding $5 \mathrm{~mm}$. $\mathrm{Hg}$ to the $\mathrm{Po}_{2}$ of the expired sample to give an estimate of the mean alveolar $\mathrm{Po}_{2}$, and subtracting the alveolar capillary oxygen difference estimated as $\mathrm{Vo}_{2} \div \mathrm{D}_{\mathrm{L}} \mathrm{O}_{2}$. Oxygen uptake $\left(\mathrm{V}_{2}\right)$ was taken from tables, assuming a metabolic rate 20 per cent above basal, and $D_{L} O_{2}$ was assumed to be 1.23 times $D_{L} C O$. The value obtained for $\theta$ was corrected proportionately for changes in the venous hæmatocrit.

Two or three measurements of $D_{L}$ and $\theta$ were obtained at both levels of oxygen tension in most of these subjects and the mean values used in the subsequent calculations. The membrane component of carbon monoxide transfer $\left(D_{M}\right)$ and the pulmonary capillary volume $(\mathrm{Vc})$ were obtained from the simultaneous equations $\frac{1}{D_{L}}=\frac{1}{D_{M}}+\frac{1}{\theta \text {.Vc }}$ at each oxygen tension. A standard value for the transfer factor $\left(D_{L}\right)$ at an oxygen tension of about $120 \mathrm{~mm}$. $\mathrm{Hg}$ was obtained by putting $\theta=1$. The graphical solution of the equation is shown in Fig. 2 in which $\frac{1}{\mathrm{D}_{\mathrm{L}}}$ is plotted against $\frac{1}{\theta}$ which is linearly related to $\mathrm{Po}_{2}$. The transfer factors $\left(\mathrm{D}_{\mathrm{L}}\right.$ and $\mathrm{D}_{\mathrm{M}}$ ) are expressed throughout in $\mathrm{ml} . / \mathrm{mm}$. $\mathrm{Hg} / \mathrm{min}$., $\theta \mathrm{in} \mathrm{ml} . \mathrm{CO} / \mathrm{ml}$. blood $/ \mathrm{mm}$. $\mathrm{Hg} / \mathrm{min}$., and capil-

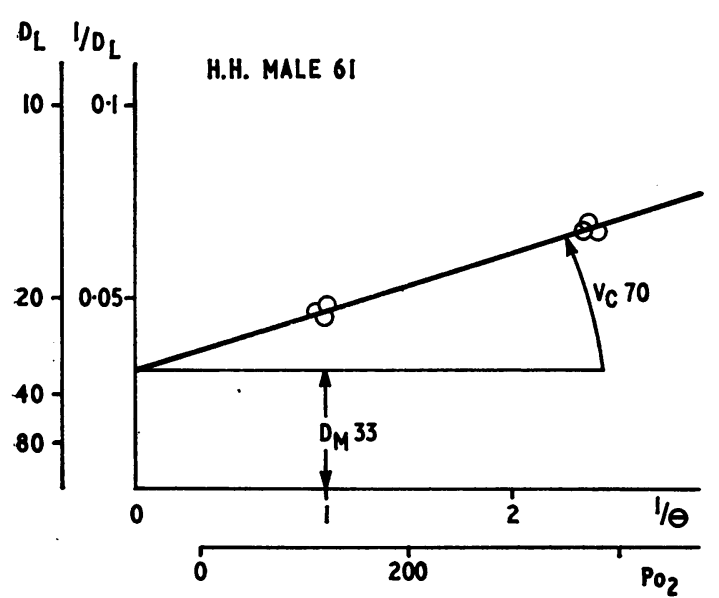

FIG. 2.-Graphical analysis of the components of gas transfer. Measurements of gas transfer $\left(D_{L}\right)$ at two levels of oxygen tension are shown. The ordinate is the resistance to gas transfer $\left(1 / D_{L}\right) ; D_{L}$ is shown alongside on an inverted scale. The abscissa $(1 / \theta)$ is linearly related to $\mathbf{P O}_{2}$. The change in gas transfer with increasing oxygen tension gives an estimate of capillary volume (Vc). The remaining resistance to gas transfer is the membrane component (DM). lary volume (Vc) in $\mathrm{ml}$. The transfer factors are expressed in terms of surface area to correct for variations in body size. Values more than two standard errors from the regression for age in normal subjects (Hamer, 1962) were regarded as abnormal. Lung volumes were expressed as percentages of the values predicted for residual volume and vital capacity in Table X of Needham, Rogan, and McDonald (1954), corrected to BTPS.

Cardiac catheterization was performed within a few days of the gas transfer measurements. Pressures were measured with Sanborn manometers with optimal damping, and were corrected to a base-line at the mid chest. Transseptal left atrial puncture was performed in 5 patients; in the remainder the mean pulmonary artery wedge pressure was used as an estimate of left atrial pressure. The cardiac output was measured by the Fick principle, oxygen consumption being measured by collecting expired air for 3 to 5 minutes. In 4 patients oxygen consumption was estimated from tables as 10 per cent above the basal levels. Blood oxygen saturations were measured by a Kipp Hæmoreflector or by the Haldane method. Cardiac output and pulmonary vascular resistance were expressed in terms of body surface area.

\section{Results}

The lung volumes and gas transfer factors obtained in each subject are shown in Table II. The alveolar volume was between 60 and 121 per cent of the predicted normal value, and was less than 75 per cent of normal in 14 patients. The lung volume using the air mixture was an average 4 per 
TABLE II

Gas Transfer Measurements

\begin{tabular}{|c|c|c|c|c|c|c|c|c|c|c|c|c|c|c|c|}
\hline \multirow{2}{*}{$\begin{array}{l}\text { Serial } \\
\text { No. }\end{array}$} & \multirow{2}{*}{$\begin{array}{c}\begin{array}{c}\text { Alveolar } \\
\text { volume }\end{array} \\
\begin{array}{c}\text { ml. } \% \mathbf{N} \\
\text { BTPS }\end{array} \\
\end{array}$} & \multirow{2}{*}{$\begin{array}{c}\begin{array}{c}\text { Residual } \\
\text { volume }\end{array} \\
\begin{array}{c}\text { ml. } \% \mathbf{N} \\
\text { BTPS }\end{array} \\
\end{array}$} & \multicolumn{4}{|c|}{$\mathbf{D}_{\mathrm{L}}$} & \multicolumn{3}{|c|}{$1 / \theta$} & \multicolumn{6}{|c|}{ Gas transfer results per m. ${ }^{2}$ BSA $^{*}$} \\
\hline & & & \multicolumn{2}{|c|}{ air } & \multicolumn{2}{|c|}{ oxygen } & \multicolumn{2}{|c|}{ air } & oxygen & \multirow[t]{2}{*}{$D_{L}$} & \multirow[t]{2}{*}{$\mathbf{D}_{\mathbf{M}}$} & \multirow[t]{2}{*}{ Vc } & \multirow[t]{2}{*}{$\mathbf{D}_{\mathbf{L}}$} & \multirow[t]{2}{*}{$D_{M}$} & \multirow[t]{2}{*}{$\mathrm{Vc}$} \\
\hline & & & & & & & ous $m$ & nitr & tenosis & & & & & & \\
\hline $\begin{array}{r}1 \\
2 \\
4 \\
6 \\
8 \\
9 \\
11 \\
12\end{array}$ & \begin{tabular}{rr|}
$\mathbf{4 7 4 0}$ & $\mathbf{7 9}$ \\
$\mathbf{5 5 2 0}$ & 84 \\
$\mathbf{5 0 8 0}$ & 95 \\
$\mathbf{4 7 8 0}$ & $\mathbf{1 0 7}$ \\
$\mathbf{3 8 5 0}$ & 81 \\
$\mathbf{5 8 3 0}$ & $\mathbf{9 7}$ \\
$\mathbf{4 0 8 0}$ & $\mathbf{8 1}$ \\
$\mathbf{4 6 0 0}$ & $\mathbf{1 0 1}$
\end{tabular} & $\left|\begin{array}{ll}2450 & 114 \\
3170 & 122 \\
1730 & 118 \\
2300 & 133 \\
2100 & 127 \\
2520 & 112 \\
1860 & 126 \\
2440 & 151\end{array}\right|$ & $\begin{array}{l}23.8 \\
15.7 \\
19.6 \\
18.3 \\
23 \cdot 4 \\
17.1 \\
24.7 \\
18.8\end{array}$ & $\begin{array}{l}20.6 \\
22.5 \\
18.7 \\
22 \cdot 4 \\
17.7\end{array}$ & $\begin{array}{l}17.9 \\
9.9 \\
13.4 \\
10.7 \\
13.7 \\
10.4 \\
19.1 \\
12.1\end{array}$ & $\begin{array}{l}9.5 \\
11.3 \\
14.8 \\
10.7 \\
15.4 \\
11.6\end{array}$ & $\begin{array}{l}0.85 \\
0.94 \\
0.99 \\
0.86 \\
1.08 \\
0.96 \\
1.07 \\
0.95\end{array}$ & $\begin{array}{l}0.99 \\
1.05 \\
0.96 \\
1.06 \\
0.96\end{array}$ & $\left|\begin{array}{ll}2.02 & \\
2.41 & 2.32 \\
2.96 & 2.93 \\
1.97 & \\
2.62 & 2.72 \\
2.45 & 2.33 \\
2.78 & 2.83 \\
2.14 & 2 \cdot 12\end{array}\right|$ & $\begin{array}{l}23.0 \\
15.3 \\
20.7 \\
16.8 \\
23.6 \\
17.6 \\
23.8 \\
17.6\end{array}$ & $\begin{array}{l}32 \\
27 \\
30 \\
41 \\
39 \\
34 \\
31 \\
29\end{array}$ & $\begin{array}{r}81 \\
36 \\
69 \\
29 \\
60 \\
37 \\
108 \\
44\end{array}$ & $\begin{array}{r}13.4 \\
9.9 \\
15 \cdot 2 \\
10.1 \\
15 \cdot 6 \\
9.9 \\
15 \cdot 8 \\
12.2\end{array}$ & $\begin{array}{l}27 \\
18 \\
22 \\
25 \\
26 \\
19 \\
21 \\
20\end{array}$ & $\begin{array}{l}47 \\
23 \\
51 \\
17 \\
40 \\
21 \\
72 \\
31\end{array}$ \\
\hline $\begin{array}{l}17 \\
18\end{array}$ & $\begin{array}{ll}4820 & 64 \\
2970 & 74\end{array}$ & $\begin{array}{ll}2300 & 86 \\
1380 & 81\end{array}$ & $\begin{array}{l}11.7 \\
15.8 \\
15.8\end{array}$ & $\begin{array}{l}22 \cdot 5 \\
16 \cdot 2\end{array}$ & $\begin{array}{l}12.9 \\
16 \cdot 2 \\
11.2\end{array}$ & $\begin{array}{l}15.4 \\
11.4\end{array}$ & $\begin{array}{l}0.89 \\
1.03 \\
1.01\end{array}$ & $\begin{array}{l}0.90 \\
1.02\end{array}$ & $\begin{array}{ll}2.09 & 2.12 \\
2.59 & 2.12 \\
2.64 & 2.88\end{array}$ & $\begin{array}{l}21 . \\
16\end{array}$ & $\begin{array}{l}30 \\
21\end{array}$ & $\begin{array}{l}75 \\
72\end{array}$ & $\begin{array}{l}10 \cdot 7 \\
12.8\end{array}$ & $\begin{array}{l}15 \\
17\end{array}$ & $\begin{array}{l}38 \\
58\end{array}$ \\
\hline $\begin{array}{l}20 \\
21\end{array}$ & $\begin{array}{ll}3520 & 84 \\
4600 & 99\end{array}$ & $\left|\begin{array}{ll}2400 & 132 \\
2420 & 150\end{array}\right|$ & $\begin{array}{l}19.1 \\
25 \cdot 3 \\
25.3\end{array}$ & $\begin{array}{l}18 \cdot 8 \\
24 \cdot 1\end{array}$ & $\begin{array}{l}11.2 \\
11.9 \\
20.0\end{array}$ & $\begin{array}{l}11.8 \\
16.1\end{array}$ & $\begin{array}{l}1.08 \\
1.08 \\
1.15\end{array}$ & $\begin{array}{l}1.06 \\
1.10\end{array}$ & $\begin{array}{|ll|}2.64 & 2.99 \\
2.71 & 2.99 \\
\end{array}$ & $\begin{array}{l}19.5 \\
24.4\end{array}$ & 32 & $\begin{array}{r}56 \\
101\end{array}$ & $\begin{array}{l}12.5 \\
16.3\end{array}$ & $\begin{array}{l}19 \\
21\end{array}$ & $\begin{array}{l}36 \\
67\end{array}$ \\
\hline $\begin{array}{l}25 \\
33\end{array}$ & $\begin{array}{ll}3100 & 66 \\
3550 & 70\end{array}$ & $\begin{array}{ll}1600 & 111 \\
1630 & 108\end{array}$ & $\begin{array}{l}22.4 \\
18.7 \\
24.9\end{array}$ & $\begin{array}{l}17 \cdot 4 \\
24 \cdot 6\end{array}$ & $\begin{array}{l}16.2 \\
13.6 \\
18.4\end{array}$ & $\begin{array}{l}14 \cdot 4 \\
19.8\end{array}$ & $\begin{array}{l}1.07 \\
0.95 \\
0.91\end{array}$ & $\begin{array}{l}0.95 \\
0.92\end{array}$ & $\begin{array}{|ll|}2.43 & 2.41 \\
2.38 & 2.29 \\
2.38 & 2.39\end{array}$ & $\begin{array}{l}17 \cdot 8 \\
23 \cdot 6\end{array}$ & 22 & $\begin{array}{r}88 \\
105\end{array}$ & $\begin{array}{l}11 \cdot 5 \\
14 \cdot 4\end{array}$ & $\begin{array}{l}14 \\
19\end{array}$ & $\begin{array}{l}57 \\
64\end{array}$ \\
\hline $\begin{array}{l}35 \\
36 \\
40\end{array}$ & $\begin{array}{rr}3950 & 86 \\
5490 & 121 \\
4210 & 98\end{array}$ & $\begin{array}{ll}1910 & 114 \\
2810 & 172 \\
2160 & 125\end{array}$ & $\begin{array}{l}17.9 \\
20.7 \\
18.4 \\
17.3\end{array}$ & $\begin{array}{l}16 \cdot 4 \\
20 \cdot 0 \\
16 \cdot 6\end{array}$ & $\begin{array}{l}11.8 \\
11.8 \\
14.3\end{array}$ & $\begin{array}{l}12 \cdot 3 \\
11.7 \\
12 \cdot 8\end{array}$ & $\begin{array}{l}0.86 \\
0.99 \\
0.82 \\
0.82\end{array}$ & $\begin{array}{l}0.89 \\
1.01 \\
0.82\end{array}$ & $\left|\begin{array}{ll}2.00 & 2.03 \\
2.41 & 2.23 \\
2.08 & 1.98 \\
2.96\end{array}\right|$ & $\begin{array}{l}16 \cdot 5 \\
20 \cdot 3 \\
16 \cdot 7\end{array}$ & $\begin{array}{l}24 \\
40 \\
22\end{array}$ & $\begin{array}{l}53 \\
42 \\
72\end{array}$ & $\begin{array}{l}11 \cdot 2 \\
12 \cdot 7 \\
11 \cdot 4\end{array}$ & $\begin{array}{l}16 \\
25 \\
15\end{array}$ & $\begin{array}{l}36 \\
26 \\
49\end{array}$ \\
\hline
\end{tabular}

Serious mitral stenosis with moderate incompetence

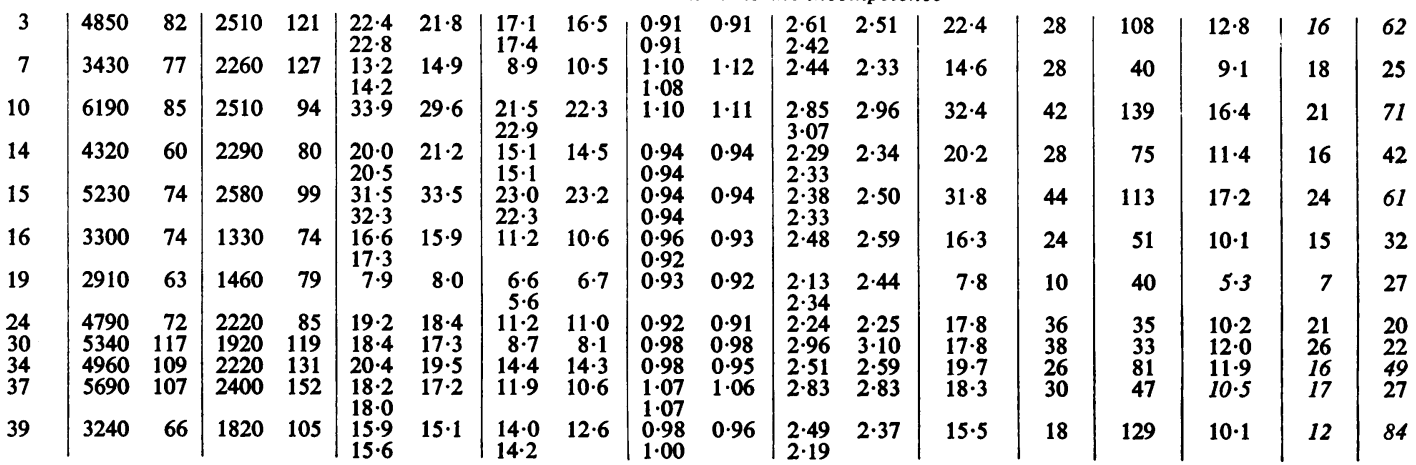

Severe mitral incompetence

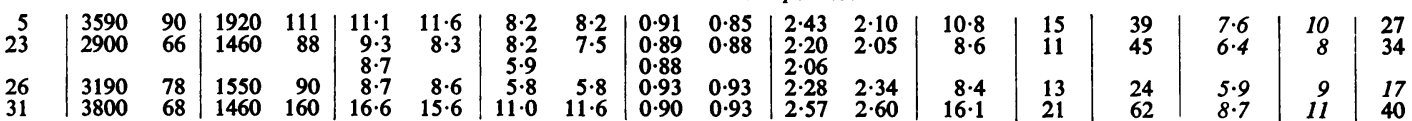

Mild mitral valve disease

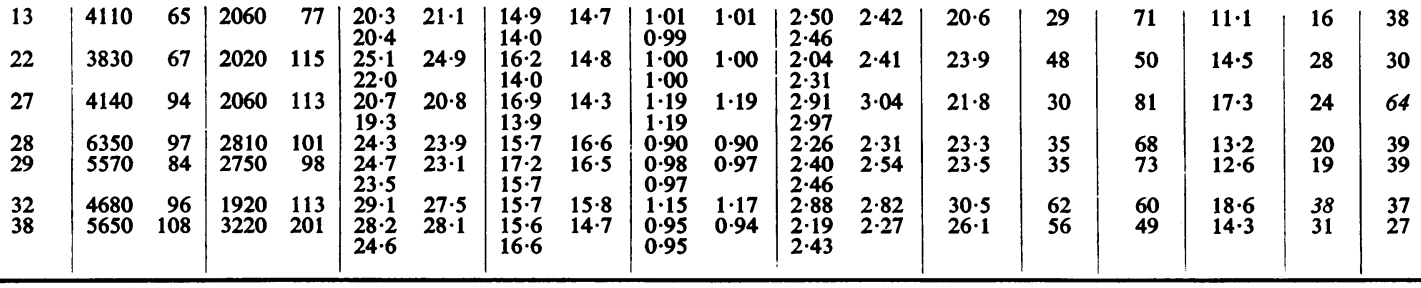

* Abnormal values in italics.

$\mathrm{D}_{\mathrm{L}}$ and $\mathrm{D}_{\mathrm{M}}$ in $\mathrm{ml} . / \mathrm{mm}$. $\mathrm{Hg} / \mathrm{min}$.

$\theta$ in $\mathrm{ml}$. $\mathrm{CO} / \mathrm{ml}$. blood $/ \mathrm{mm}$. $\mathrm{Hg} / \mathrm{min}$.

$\mathrm{Vc}$ in $\mathrm{ml}$. 
(a)

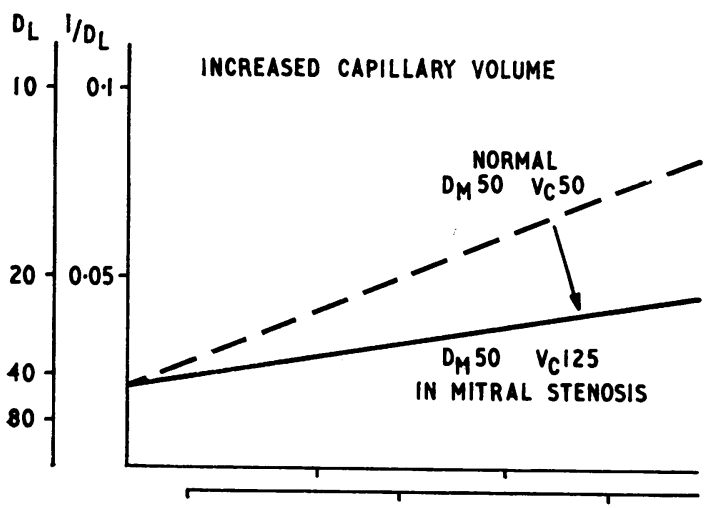

(b)

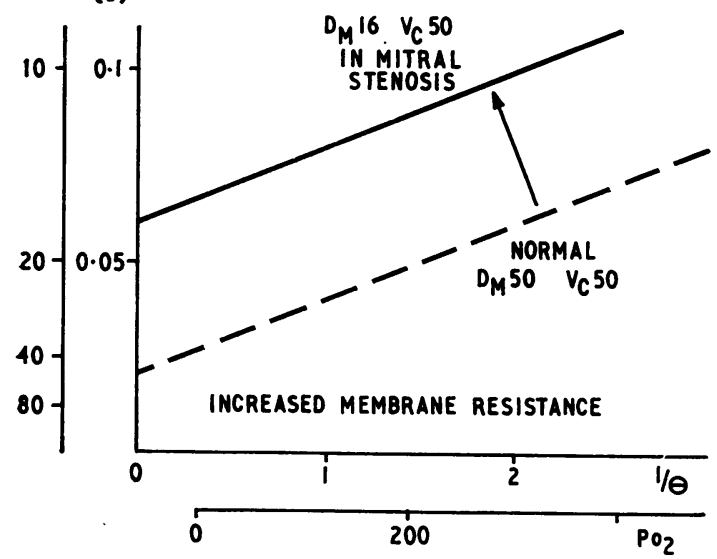

FIG. 3.-Changes in the components of gas transfer in mitral valve disease. Typical changes in gas transfer in mitral valve disease are shown on the same diagram as Fig. 2. An increase in capillary volume (Vc) produces a decrease in the slope of the line. A reduction in the membrane component (DM), i.e. an increase in membrane resistance, leads to a higher intercept on the vertical axis. cent larger than with the oxygen mixture, but in only 7 patients was the difference greater than 10 per cent. The gas transfer results were in no way unusual in these cases. The patients with reduced $D_{L}$ or $D_{M}$ tended to have small lung volumes.

The main abnormalities in gas transfer were a decrease in the membrane component $\left(D_{M}\right)$, indicating an increased resistance to the movement of carbon monoxide, and an increase in pulmonary capillary volume (Vc) (Fig. 3). The overall gas transfer factor $\left(D_{L}\right)$ was often reduced when there was impairment of $D_{M}$ alone, but usually failed to indicate any abnormality when a reduction in $D_{M}$ was associated with an abnormally large capillary volume (Vc). There was no relation between the abnormalities of gas transfer and the duration of dyspnœa, the presence of recent severe congestion, recurrent bronchitis, or atrial fibrillation. The changes in the patients with serious mitral stenosis and incompetence were similar to those found in uncomplicated mitral stenosis of sufficient severity to need operation. $D_{M}$ was reduced in $12(41 \%)$ and Vc increased in $11(38 \%)$ of these 29 patients. The pattern in the relatively few patients with severe mitral incompetence differed considerably; all showed gross reduction in $D_{M}$ but a normal value for Vc. Those with mild disease showed no abnormalities apart from an increase in $\mathrm{Vc}$ in one subject. There were three further minor abnormalities; in two there was a reduction of capillary volume (Vc) of border-line significance, and in a third patient $\mathbf{D}_{\mathbf{M}}$ was abnormally large.

TABLE III

Average Values for Components of Gas Transfer for Various Types of Mitral Valve Disease

\begin{tabular}{|c|c|c|c|c|}
\hline & No. & (ml./mm. $\stackrel{\mathrm{D}_{\mathrm{L}}}{\left.\mathrm{Hg} / \mathrm{min} . / \mathrm{m} .{ }^{2}\right)}$ & $\begin{array}{c}\mathrm{D}_{\mathrm{M}} \\
\left(\mathrm{ml} . / \mathrm{mm} . \mathrm{Hg} / \mathrm{min} . / \mathrm{m} .{ }^{2}\right)\end{array}$ & $\begin{array}{c}\mathrm{Vc} \\
\left(\mathrm{ml} . / \mathrm{m} .{ }^{2}\right)\end{array}$ \\
\hline $\begin{array}{l}\text { Normal subjects (Hamer, 1962) } \\
\text { Serious uncomplicated MS .. } \\
\text { Serious MS with MI } \\
\text { All patients with serious MS } \\
\text { Severe mitral incompetence .. } \\
\text { Mild mitral valve disease .. }\end{array}$ & $\begin{array}{r}25 \\
17 \\
12 \\
29 \\
4 \\
7\end{array}$ & $\begin{aligned} 15 \cdot 8 \\
12 \cdot 7 \\
11 \cdot 4 \\
12 \cdot 2 \\
7 \cdot 2 \\
14 \cdot 5\end{aligned}$ & $\begin{array}{l}28 \\
20 \\
17 \\
19 \\
10 \\
25\end{array}$ & $\begin{array}{l}35^{*} \\
43 \\
44 \\
43 \\
30 \\
39\end{array}$ \\
\hline
\end{tabular}

* Omits 3 unusually large values.

MS = mitral stenosis; $\mathbf{M I}=$ moderate incompetence. 
The mean values for the components of gas transfer are shown in Table III where the findings are compared to the results in normal subjects. The 29 patients with serious mitral stenosis (including the 12 with some degree of incompetence) had significantly lower values for $D_{L}$ and $D_{M}$ than the 25 normal subjects studied previously (Hamer, 1962), and the capillary volume $(\mathrm{Vc})$ was significantly larger than normal $(\mathrm{t}=5 \cdot 1,9 \cdot 4$, and $2 \cdot 4$ respectively). The findings are expressed graphically in Fig. 4. The 4 patients with severe MI have very low values for $D_{M}$, and one patient with serious MS complicated by $\mathrm{MI}$ and pulmonary hypertension falls in the same range.

Cardiac catheterization was performed in 21 patients. The incidence of the various types of mitral valve disease differed from that in the study as a whole, as catheterization was not considered necessary in many with uncomplicated mitral stenosis, and those patients classified as mild mitral valve disease often presented diagnostic problems requiring hæmodynamic study. The mean pulmonary pressures, cardiac output, and pulmonary vascular resistance are shown in Table IV. In view of the small numbers involved the various types of mitral valve disease have not been analysed separately. Gas transfer measurements showed a reduced $D_{L}$ in 5 , reduced $D_{M}$ in 9 , and an increased Vc in 6 patients.

Regression analysis shows no significant correlation between the pulmonary vascular pressures and the gas transfer findings, though the relation between the wedge pressure and Vc is suggestive. However, there is a significant relation between pulmonary blood flow and $D_{L}$ and $D_{M}$, and the result approaches significance in the case of Vc. The pulmonary vascular resistance is also close to a significant correlation with $D_{L}$ and $D_{M}$ (Fig. 5).

The mean arterial oxygen saturation was 93.5 per cent and was below 95 per cent in 12 patients. There was no relation between arterial oxygen saturation and gas transfer measurements.

\section{Discussion}

The histological changes in the lungs in mitral valve disease were first described in detail
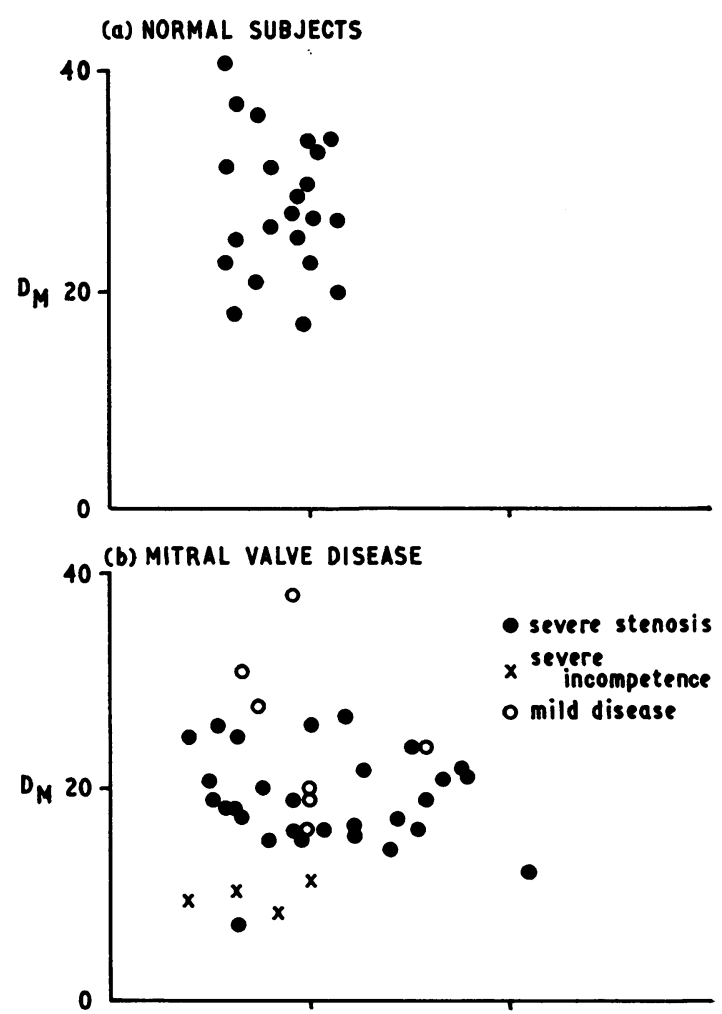

(c) CHANGES IN DM and $V_{C}$ in MITRAL

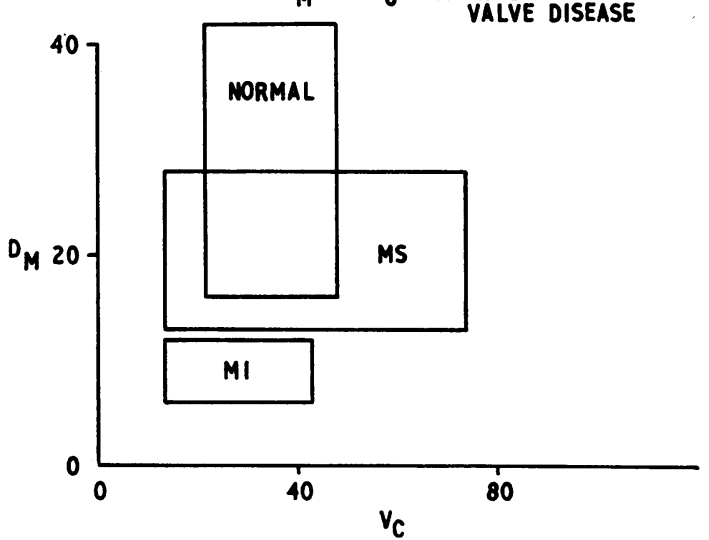

FIG. 4.-Comparison of the components of gas transfer in normal subjects and in mitral valve disease. The changes produced by mitral valve disease are shown diagrammatically by plotting $D_{M}$ on the vertical and Vc on the horizontal axis. All values are expressed in terms of body surface area. The patients with severe mitral stenosis show larger values for $\mathrm{Vc}$ and a tendency to lower $\mathrm{D}_{\mathbf{M}}$ than the normal subjects (Hamer, 1962). These changes are shown by the overlapping rectangles in the lowest diagram. The small number of patients with severe mitral incompetence had more serious reduction in $\mathbf{D}_{\mathbf{M}}$. 
TABLE IV

Cardiac Catheterization Findings

\begin{tabular}{|c|c|c|c|c|c|}
\hline Serial No. & $\begin{array}{c}\text { Mean PA wedge } \\
\text { pressure } \\
\text { (mm. Hg) }\end{array}$ & $\begin{array}{c}\text { Mean PA } \\
\text { pressure } \\
(\mathrm{mm} . \mathrm{Hg})\end{array}$ & $\underset{\left(1 . / \mathrm{min} . / \mathrm{m} .^{2}\right)}{\text { Cardiac index }}$ & $\begin{array}{l}\text { Pulmonary } \\
\text { vascular } \\
\text { resistance } \\
\text { (units, } m .{ }^{2} \text { ) }\end{array}$ & $\begin{array}{l}\text { Arterial oxygen } \\
\text { saturation } \\
(\%, \text { Kipp) }\end{array}$ \\
\hline \multicolumn{6}{|c|}{ Serious mitral stenosis } \\
\hline $\begin{array}{r}1 \\
9 \\
11 \\
18 \\
35\end{array}$ & $\begin{array}{l}17 \\
17 \\
18 \\
41 \\
251 \mathrm{la}\end{array}$ & $\begin{array}{l}31 \\
26 \\
27 \\
77 \\
55\end{array}$ & $\begin{array}{r}2 \cdot 8 \\
1 \cdot 3 \\
2 \cdot 7 \\
1 \cdot 8 \\
1 \cdot 7\end{array}$ & $\begin{array}{r}5 \\
7 \\
3 \\
20 \\
18\end{array}$ & $\begin{array}{l}98 \\
92 \\
98 \\
92 \\
94\end{array}$ \\
\hline \multicolumn{6}{|c|}{ Serious MS mitral stenosis with moderate incompetence } \\
\hline $\begin{array}{l}10 \\
14 \\
15 \\
16 \\
19 \\
24 \\
34 \\
37 \\
39\end{array}$ & $\begin{array}{l}25 \\
40^{\mathrm{la}} \\
30^{\mathrm{la}} \\
24 \\
30 \\
16 \\
19 \mathrm{la} \\
16 \\
24\end{array}$ & $\begin{array}{l}31 \\
60 \\
65 \\
29 \\
55 \\
26 \\
26 \\
22 \\
33\end{array}$ & $\begin{array}{l}3 \cdot 1^{*} \\
2 \cdot 8 \\
2 \cdot 4 \\
2.9 \\
1.7^{*} \\
1 \cdot 5 \\
2.9 \\
1 \cdot 8 \\
2 \cdot 8\end{array}$ & $\begin{array}{r}2 \\
7 \\
15 \\
1 \\
15 \\
7 \\
2 \\
3 \\
3\end{array}$ & $\begin{array}{l}96 \mathrm{H} \\
92 \\
87 \\
95 \mathrm{H} \\
88 \\
93 \mathrm{H} \\
99 \\
= \\
-\end{array}$ \\
\hline \multicolumn{6}{|c|}{ Severe mitral incompetence } \\
\hline $\begin{array}{r}5 \\
23 \\
31\end{array}$ & $\begin{array}{l}17 \\
14^{1 \mathrm{a}} \\
17\end{array}$ & $\begin{array}{l}32 \\
60 \\
26\end{array}$ & $\begin{array}{l}2 \cdot 2 \\
1 \cdot 7 \\
1 \cdot 8^{*}\end{array}$ & $\begin{array}{r}7 \\
27 \\
5\end{array}$ & $\begin{array}{l}92 \\
90 \mathrm{H} \\
98\end{array}$ \\
\hline \multicolumn{6}{|c|}{ Mild mitral valve disease } \\
\hline $\begin{array}{l}13 \\
22 \\
29 \\
32\end{array}$ & $\begin{array}{l}20 \\
12 \\
14 \\
13\end{array}$ & $\begin{array}{l}27 \\
18 \\
22 \\
19\end{array}$ & $\begin{array}{l}2 \cdot 4 \\
3 \cdot 7 \\
3 \cdot 2 \\
3 \cdot 2^{*}\end{array}$ & $\begin{array}{l}3 \\
2 \\
3 \\
2\end{array}$ & $\begin{array}{l}91 \mathrm{H} \\
94 \mathrm{H} \\
98 \\
89\end{array}$ \\
\hline
\end{tabular}

la $=$ direct left atrial pressure.

$\mathbf{H}=$ oxygen saturation by Haldane method.

* oxygen consumption estimated from table.

(Parker and Weiss, 1936). They found dilatation and an increase in number of the capillaries in the upper parts of the lung. There was interstitial œdema, producing thickening of the capillary basement membrane, and in the lower parts of the lungs the alveolar walls were considerably thickened by an increase in the interstitial collagen layer. They stated that "the nature of these structural changes is such that they interfere with the vital pulmonary function of gaseous exchange".

Early studies of the absorption of gases in the lungs in mitral stenosis appeared to confirm the conclusions of Parker and Weiss (1936). Analysis of the alveolar-arterial oxygen gradient (Lilienthal et al., 1946; Riley, Cournand, and Donald, 1951) showed interference with oxygenation of the arterial blood in patients with mitral valve disease (Blount, McCord, and Anderson, 1952) and suggested that the movement of oxygen from alveoli to capillaries was impaired in many cases (Blount et al., 1953; Carroll, Cohn, and Riley, 1953; Fowler, Cubberly, and Dorney, 1954; Cosby et al., 1957). These findings were widely accepted as the functional counterpart of the histological changes (Blount et al., 1953; Scott, 1954), though Williams (1953) pointed out that the abnormalities were not severe enough to reduce the resting arterial oxygen saturation.

Further study of the lungs in mitral stenosis (Goodale et al., 1955) showed that the histological changes were usually less severe than in the few florid cases described by Parker and Weiss (1936). O'Neal et al. (1957) found fibrous thickening of the alveolar walls in less than 10 per cent of the area of lung examined in a large number of patients with serious mitral stenosis. They reported that 

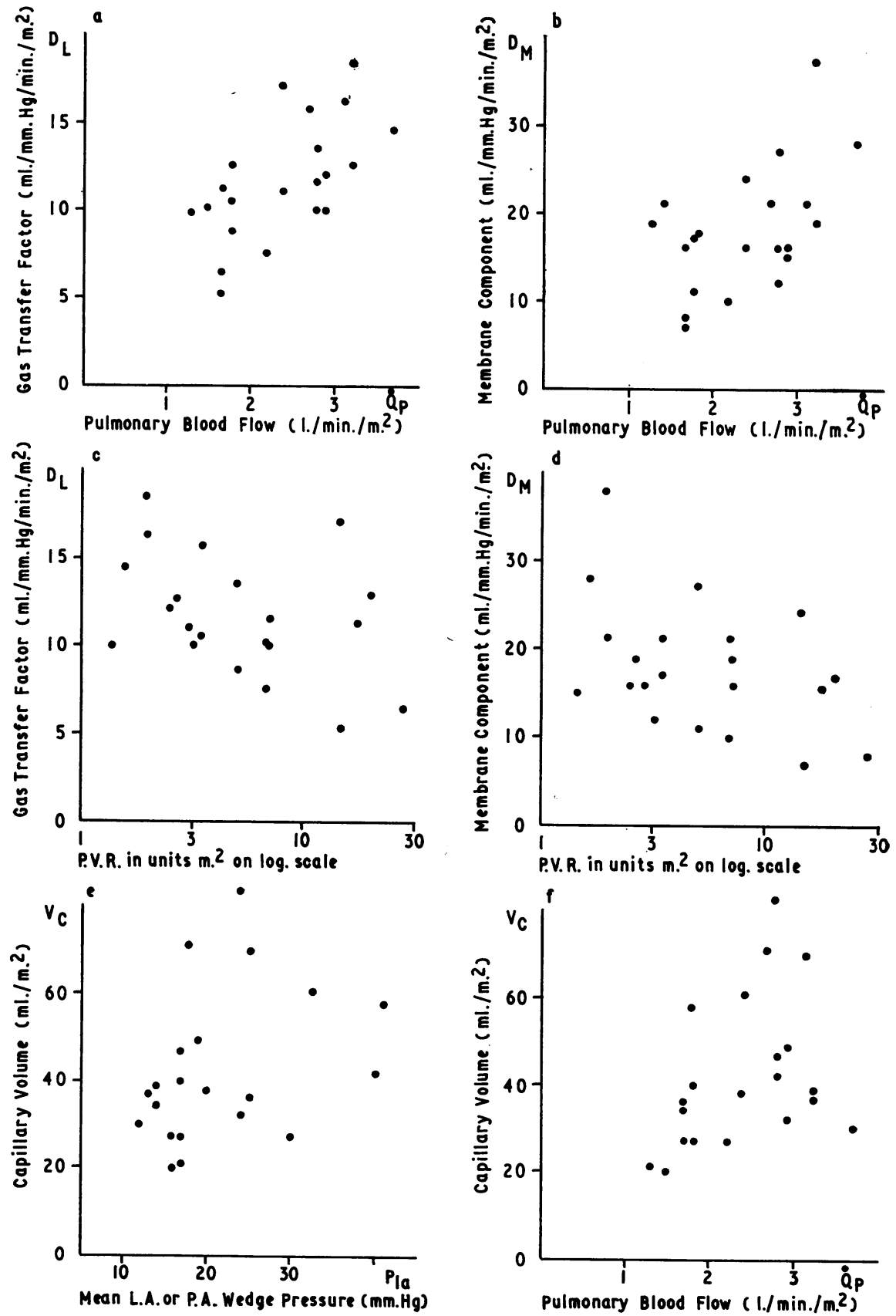

Fig. 5.-Relation between gas transfer measurements and findings at cardiac catheterization. Both over-all gas transfer $\left(D_{L}\right)$ and the membrane component $\left(D_{M}\right)$ are significantly related to the pulmonary blood flow $(r=0.59$ and $0.51, p<0.05)$, and the relation to the pulmonary vascular resistance approaches this level of significance when the resistance data are expressed on a logarithmic scale $(\mathrm{r}=-0.41$ and $-0.43, \mathrm{p}<0.10)$. The capillary volume $(\mathrm{Vc})$ shows a tendency to increase with left atrial pressure and with pulmonary blood flow $(\mathrm{r}=0 \cdot 34$ and $0 \cdot 38, \mathrm{p}=c .0 \cdot 10)$. 
capillary dilatation was usually slight and pericapillary œema rare. These studies suggested that changes in the alveolar walls were not in fact of physiological importance.

The introduction of carbon monoxide as an indicator of the behaviour of oxygen in the lungs (Krogh, 1915) led to the development of convenient techniques for the measurement of gas transfer (Forster et al., 1954; Filley, MacIntosh, and Wright, 1954; Bates, Boucot, and Dormer, 1955). These methods showed somewhat less abnormality in mitral valve disease than the oxygen technique. Using the single-breath method, Auchincloss, Gilbert, and Eich (1959) and Denolin, Englert, and de Coster (1960) found impaired gas transfer only in the more severely affected patients, and Burrows et al. (1961) found significantly low values in only 2 of 52 subjects with "acquired heart disease". Reid and Stevenson (1963), with a steady-state method, found little abnormality at rest, though gas transfer was reduced on effort in some patients with serious disease, and Driscoll, Cugell, and Tobin (1963) found no significant disturbance in their patients.

Some of the apparent discrepancy between the histological changes in the lungs and the gas transfer measurements is explained by the finding (Roughton and Forster, 1957) that much of the resistance to gas transfer is due to the slow chemical reaction in the red cells. An increase in the pulmonary capillary volume will improve gas transfer and tend to counteract the effect of an increase in the thickness of the alveolar capillary membrane. Further studies have shown that the chemical reaction in the red cells is also a limiting factor in oxygen transfer (Staub, Bishop, and Forster, 1961), and the rate of reaction varies in a complex manner with changes in oxygen tension. As the original method used to measure the movement of oxygen across the alveolar walls (Riley et al., 1951) was based on the assumption that the process was not affected by a considerable reduction in oxygen tension, the findings with this technique must be re-evaluated. Preliminary work suggests that there is much less resistance to the passage of oxygen across the alveolar-capillary membrane than had been suggested by work with the Riley method (Staub, 1963).

As $D_{L}$ varies with lung volume, any difference in lung volume at the two levels of oxygen tension will lead to an error in the estimate of $D_{M}$ and Vc. Previous work (Hamer, 1963b) suggests that $D_{L}$ falls about 5 per cent for a 10 per cent reduction in lung volume in the range near total lung capacity. The tendency in the present study was to a smaller lung volume at the higher oxygen tension, tending to produce an overestimate of $\mathrm{D}_{\mathbf{M}}$ and an underestimate of $\mathrm{Vc}$ of similar degree to the difference between the lung volumes. In the worst case there was a 24 per cent difference between the lung volumes at the two levels of oxygen tension. However, the findings in the patients with the larger differences in lung volume are not unusual, and as the mean difference is less than 5 per cent this effect is not likely to produce a serious error. In fact the changes produced in this way are in the reverse direction to the abnormalities in $D_{M}$ and $V c$ that result from mitral valve disease and may play a part in reducing the apparent effects of the cardiac lesion.

There is no simple relation between gas transfer and lung volume. In normal subjects the membrane component $\left(D_{M}\right)$ varies with the degree of inflation of the lungs, but there is evidence that the capillary volume increases when the lung is deflated (Hamer, 1963b; Howell et al., 1961). As a result the over-all transfer factor $\left(D_{L}\right)$ falls less than expected with reduction in lung volume. In disease states there is a tendency for small lung volumes to be associated with reduced values for $D_{L}$ (Burrows et al., 1961), presumably as both lung volume and gas transfer are similarly affected by the disease process. These workers found lower values for $D_{L}$ in their "acquired heart disease" patients with reduced lung volumes, as in the present study, where the effect of changes in lung volume is confined to the membrane component $\left(D_{M}\right)$.

The tendency to an increase in pulmonary capillary volume in mitral valve disease is consistent with the histological findings, but the changes were found only in 11 of 29 patients $(38 \%)$ with serious stenosis. The reduced membrane component $\left(D_{M}\right)$ would similarly be expected from the histological appearances, but again only 12 of the 29 patients $(41 \%)$ with serious stenosis were affected. As expected, the over-all measurement of gas transfer $\left(D_{L}\right)$ was a poor guide to the extent of the abnormality as in many cases a low value for $D_{M}$ was masked by an increase in Vc. In fact a reduced $D_{L}$ was found in only 7 of the 16 patients with a low membrane component $\left(D_{M}\right)$. 
These findings are similar to those reported in mitral stenosis by other workers. McNeill et al. (1958) found a large capillary volume in one patient, and Bates et al. (1960), using a steady state method, found an increased capillary volume or an impaired membrane component in 3 of their 5 patients. ${ }^{*}$ Flatley et al. (1962) studied 20 patients by a slightly different technique from that used in the present work (Hamer, 1963c) and found an increase in capillary volume with the increasing severity of the stenosis, and also a tendency to a reduced membrane component. Daly et al. (1964) have recently reported similar results in 10 patients.

The abnormal distribution of ventilation and blood flow in the lungs in mitral stenosis probably affects the abnormalities of gas transfer (Hamer, 1963c). The gravitational increase in blood flow in the lower part of the lungs in normal subjects is lost as the pulmonary venous pressure rises, and with increasing pulmonary arterial hypertension the flow becomes greater in the upper parts of the lungs (Dollery and West, 1960). In addition there is probably uneven distribution of ventilation (Raine and Bishop, 1963) and perfusion (Bishop et al., 1962) at alveolar level. These changes reduce the contact between alveolar gas and capillary blood.

Although both components of gas transfer will be reduced by uneven distribution there is evidence that the main effect in measurements made by the carbon monoxide method will be on the membrane component (Hamer, 1964). Uneven distribution effects are probably partly responsible for the low values for the membrane component $\left(D_{M}\right)$ in this study, and may be diminishing the effects of a real increase in pulmonary capillary volume.

Comparison of the hæmodynamic findings and the changes in gas transfer, in spite of an interval of several days between the measurements, indicates a correlation between the membrane component $\left(D_{M}\right)$ and pulmonary blood flow or pulmonary vascular resistance, and suggests an effect on capillary volume (Vc) from an increase in pulmonary venous pressure or pulmonary blood flow. No relation could be demonstrated between the membrane component and the pulmonary venous pressure. Other workers have reported that gas transfer was more seriously affected in patients with high pulmonary vascular pressures (Denolin et al., 1960), but Flatley et al. (1962) could find no correlation between the cardiac catheterization findings and simultaneous gas transfer measurements in 10 of their patients with severe mitral stenosis.

An increase in capillary volume is found in patients with large pulmonary blood flows due to a left-to-right shunt (Bucci, Cook, and Hamann, 1961; Flatley et al., 1962). However, there is no demonstrable effect of increased flow on the capillary volume in thyrotoxicosis (Stein, Kimbel, and Johnson, 1961), in the physiological studies of Daly, Ross, and Behnke (1963), or in experiments with isolated animal lungs (Rosenberg and Forster, 1960; Burrows and Niden, 1963). These workers agree that capillary volume increases as the pulmonary venous pressure rises, probably by opening additional parts of the pulmonary vascular bed rather than by producing capillary dilatation. It seems likely that in mitral stenosis the expected increase in capillary volume from a rise in the pulmonary venous pressure is limited by a tendency to reduction in capillary volume due to a diminished pulmonary blood flow.

An increase in capillary volume might be expected to produce a large value for the membrane component by increasing the area available for diffusion. This situation has been reported in atrial septal defect (Bucci et al., 1961), and is probably responsible for the relation between the membrane component and pulmonary blood flow found in the present study. However, large physiological variations in capillary volume can occur without affecting the membrane component (Cotes, Snidal, and Shepard, 1960). No correlation could be demonstrated between the changes in the membrane component and the pulmonary venous pressure in these patients, suggesting that the increase in the diffusion surface that results from capillary dilatation under these circumstances might be masked by the associated thickening of the alveolar walls. In fact the general tendency is to a reduction in the membrane component in spite of a larger capillary bed, suggesting that the increased thickness of

* Palmer, Gee, Mills, and Bates (1963) have recently reported a study of 30 patients with mitral stenosis. They demonstrated an increase in Vc in patients with moderately severe disease, but Vc was reduced in the more seriously affected cases. $D_{M}$ was only slightly impaired. 
the alveolar-capillary membrane, or associated distribution disturbances secondary to the pulmonary venous congestion, outweigh the effects of capillary dilatation. Some of the relationship between an impaired membrane component and a low cardiac output may be due to uneven distribution effects in the lungs as a result of pulmonary vascular disease. However, the gross reduction in the membrane component in mitral incompetence may occur without serious increase in the pulmonary vascular resistance, and is probably an indication of the very low cardiac output in these patients.

Electron microscope studies have confirmed that the alveolar-capillary membrane in mitral stenosis is considerably increased in width (Schulz, 1962), but Staub (1963) has shown that the membrane component of gas transfer $\left(D_{M}\right)$ must be reduced to one-fifth of the normal value to produce any fall in arterial oxygen tension. As only the most severely affected patients show abnormalities of this degree, and there is reason to think that only part of the reduction in $D_{M}$ is due to changes in the alveolar-capillary membrane, the low arterial saturations frequently found in mitral stenosis (Driscoll et al., 1963) cannot be attributed to interference with diffusion. Uneven distribution effects are probably responsible.

\section{ConClusions}

The disturbances in the physiological behaviour of the pulmonary capillary bed have been investigated in $\mathbf{4 0}$ patients with mitral valve disease. Measurements of carbon monoxide absorption were used to calculate the pulmonary capillary volume (Vc), and the membrane component of gas transfer $\left(D_{M}\right)$, an estimate of the changes in the alveolar-capillary membrane.

Seventeen patients with serious mitral stenosis and 12 patients with serious mitral stenosis associated with moderate mitral incompetence were studied. Similar changes were found in these two groups of patients: the capillary volume $(\mathrm{Vc})$ was increased in 38 per cent and the membrane component $\left(D_{M}\right)$ was reduced in 41 per cent. These changes are consistent with the histological evidence of an increase in the size and number of the pulmonary capillaries and thickening of the alveolar walls in mitral stenosis. Four patients with severe mitral incompetence had serious impairment of the membrane component $\left(D_{M}\right)$ but normal capillary volumes $(\mathrm{Vc})$. Seven patients with mild mitral valve disease showed no consistent abnormality.

Cardiac catheterization was performed in 21 patients. The findings suggest that the capillary volume (Vc) depends on both pulmonary venous pressure and pulmonary blood flow. Variations in capillary volume would be expected to affect the membrane component $\left(D_{M}\right)$ by altering the area available for diffusion. Changes of this type in response to an increase in pulmonary venous pressure are probably masked by the associated increase in thickness of the alveolar-capillary membrane and by the effects of uneven distribution of ventilation and blood flow in the lung. However, there is a relation between the membrane component $\left(D_{M}\right)$ and pulmonary blood flow, and the serious impairment of the membrane component $\left(\mathrm{D}_{\mathbf{M}}\right)$ in severe mitral incompetence is probably related to the low cardiac output in these patients.

The increase in capillary volume $(\mathrm{Vc})$ tends to counteract the effects of the reduction in the membrane component $\left(D_{M}\right)$, so that measurements of the whole process of transfer of gas from the alveoli to the red cells, i.e. "diffusing capacity" $\left(D_{L}\right)$, are often normal in mitral valve disease. In spite of the histological findings of an increase in the thickness of the alveolar-capillary membrane, the changes in gas transfer demonstrated here are not sufficient to reduce the arterial oxygen saturation. When this occurs uneven distribution of ventilation and blood flow in the lungs are probably responsible.

I am most grateful to the Physicians of the National Heart Hospital for allowing me to study patients under their care, and particularly to Dr. Wallace Brigden, Director of the Institute of Cardiology, for his help and encouragement.

\section{REFERENCES}

Auchincloss, J. H., Gilbert, R., and Eich, R. H. (1959). The pulmonary diffusing capacity in congenital and rheumatic heart disease. Circulation, 19, 232. 
Bates, D. V., Boucot, N. G., and Dormer, A. E. (1955). The pulmonary diffusing capacity in normal subjects. J. Physiol. (Lond.), 129, 237.

—, Varvis, C. J., Donevan, R. E., and Christie, R. V. (1960). Variations in the pulmonary capillary blood volume and membrane diffusion component in health and disease. J. clin. Invest., 39, 1401.

Bishop, J. M., Harris, P., Bateman, M., and Raine, J. M. (1962). Respiratory gas exchange in mitral stenosis at three levels of inspired oxygen before and after the infusion of acetylcholine. Clin. Sci., 22, 53.

Blount, S. G., McCord, M. C., and Anderson, L. L. (1952). The alveolar-arterial oxygen pressure gradient in mitral stenosis. J. clin. Invest., 31, 840.

$-, \frac{}{-},-$ and Komesu, S. (1953). The analysis of the alveolar-arterial oxygen pressure gradient in mitral stenosis. J. Lab. clin. Med., 42, 108.

Bucci, G., Cook, C. D., and Hamann, J. F. (1961). Studies of respiratory physiology in children. VI. Lung diffusing capacity, diffusing capacity of the pulmonary membrane and pulmonary capillary blood volume in congenital heart disease. J. clin. Invest., 40, 1431.

Burrows, B., Kasik, J. E., Niden, A. H., and Barclay, W. R. (1961). Clinical usefulness of the single-breath pulmonary diffusing capacity test. Amer. Rev. resp. Dis., 84, 789.

- and Niden, A. H. (1963). Effect of vascular pressure and blood flow on CO diffusion in the perfused dog lung. J. appl. Physiol., 18, 722.

Carroll, D., Cohn, J. E., and Riley, R. L. (1953). Pulmonary function in mitral valvular disease: distribution and diffusion characteristics in resting patients. J. clin. Invest., 32, 510 .

Cosby, R. S., Stowell, E. C., Hartwig, W. R., and Mayo, M. (1957). Pulmonary function in left ventricular failure, including cardiac asthma. Circulation, 15, 492.

Cotes, J. E. (1963). Terminology for exchange of gas in the lungs. Lancet, $2,843$.

-, Snidal, D. P., and Shepard, R. H. (1960). Effect of negative intra-alveolar pressure on pulmonary diffusing capacity. J. appl. Physiol., 15, 372.

Daly, W. J., Giammona, S. T., Ross, J. C., and Feigenbaum, H. (1964). Effects of pulmonary vascular congestion on postural changes in the perfusion and filling of the pulmonary vascular bed. J. clin. Invest., 43, 68.

-, Ross, J. C., and Behnke, R. H. (1963). The effect of changes in the pulmonary vascular bed produced by atropine, pulmonary engorgement, and positive-pressure breathing on diffusing and mechanical properties of the lung. J. clin. Invest., 42, 1083 .

Denolin, H., Englert, M., and de Coster, A. (1960). La diffusion alvéolo-capillaire dans les cardiopathies. Poumon, 16,1131 .

Dollery, C. T., and West, J. B. (1960). Regional uptake of radioactive oxygen, carbon monoxide and carbon dioxide in the lungs of patients with mitral stenosis. Circulat. Res., 8, 765 .

Driscoll, J. F., Cugell, D. W., and Tobin, J. R. (1963). Carbon monoxide diffusing capacity in mitral stenosis. Circulation, 28, 713.

Filley, G. F., MacIntosh, D. J., and Wright, G. W. (1954). Carbon monoxide uptake and pulmonary diffusing capacity in normal subjects at rest and during exercise. J. clin. Invest., 33, 530.

Flatley, F. J., Constantine, H., McCredie, R. M., and Yu, P. N. (1962). Pulmonary diffusing capacity and pulmonary capillary volume in normal subjects and in cardiac patients. Amer. Heart J., 64, 159.

Forster, R. E., Fowler, W. S., Bates, D. V., and van Lingen, B. (1954). The absorption of carbon monoxide by the lungs during breathholding. J. clin. Invest., 33, 1135 .

Fowler, N. O., Cubberly, R., and Dorney, E. (1954). Pulmonary blood distribution and oxygen diffusion in mitral stenosis. Amer. Heart J., 48, 1.

Goodale, F., Sanchez, G., Friedlich, A. L., Scannell, J. G., and Myers, G. S. (1955). Correlation of pulmonary arteriolar resistance with pulmonary vascular changes in patients with mitral stenosis before and after valvulotomy. New Engl. J. Med., 252, 979.

Hamer, J. (1964). The cause of the low arterial oxygen saturation in pulmonary fibrosis. Thorax, 19, 507.

Hamer, N. A. J. (1962). The effect of age on the components of the pulmonary diffusing capacity. Clin. Sci., $23,85$.

- (1963a). Changes in the components of the diffusing capacity in pulmonary sarcoidosis. Thorax, 18, 275.

- (1963b). Variations in the components of the diffusing capacity as the lung expands. Clin. Sci., 24, 275.

- (1963c). Changes in the absorption of carbon monoxide in the lungs after breathing oxygen. Clin. Sci., 25, 385.

Howell, J. B. L., Permutt, S., Proctor, D. F., and Riley, R. L. (1961). Effect of inflation of the lung on different parts of pulmonary vascular bed. J. appl. Physiol., 16, 71 .

Jones, R. S., and Meade, F. (1961). A theoretical and experimental analysis of anomalies in the estimation of pulmonary diffusing capacity by the single breath method. Quart.J. exp. Physiol., 46, 131.

Kreuzer, F., and Yahr, W. Z. (1960). Influence of red cell membrane on diffusion of oxygen. J. appl. Physiol., 15, 1117.

Krogh, M. (1915). The diffusion of gases through the lungs of man. J. Physiol. (Lond.), 49, 271.

Lilienthal, J. L., Riley, R. L., Proemmel, D. D., and Franke, R. E. (1946). An experimental analysis in man of the oxygen pressure gradient from alveolar air to arterial blood during rest and exercise at sea level and at altitude. Amer. J. Physiol., 147, 199.

McGrath, M. W., and Thomson, M. L. (1959). The effect of age, body size and lung volume change on alveolarcapillary permeability and diffusing capacity in man. J. Physiol. (Lond.), 146, 572.

McNeill, R. S., Rankin, J., and Forster, R. E. (1958). The diffusing capacity of the pulmonary membrane and the pulmonary capillary blood volume in cardiopulmonary disease. Clin. Sci., 17, 465.

Needham, C. D., Rogan, M. C., and McDonald, I. (1954). Normal standards for lung volumes, intrapulmonary gasmixing, and maximum breathing capacity. Thorax, 9, 313. 
Ogilvie, C. M., Forster, R. E., Blakemore, W. S., and Morton, J. W. (1957). A standardized breath holding technique for the clinical measurement of the diffusing capacity of the lung for carbon monoxide. J. clin. Invest., 36,1 .

O'Neal, R. M., Thomas, W. A., Lee, K. T., and Rabin, E. R. (1957). Alveolar walls in mitral stenosis. Circulation, $15,64$.

Palmer, W. H., Gee, J. B. L., Mills, F. C., and Bates, D. V. (1963). Disturbances of pulmonary function in mitral valve disease. Canad. med. Ass. J., 89, 745.

Parker, F., and Weiss, S. (1936). The nature and significance of the structural changes in the lungs in mitral stenosis. Amer. J. Path., 12, 573.

Raine, J., and Bishop, J. M. (1963). The distribution of alveolar ventilation in mitral stenosis at rest and after exercise. Clin. Sci., 24, 63.

Reid, J. M., and Stevenson, J. G. (1963). Pulmonary diffusing capacity in mitral valve disease. Brit. Heart J., 25, 741 .

Riley, R. L., Cournand, A., and Donald, K. W. (1951). Analysis of factors affecting partial pressures of oxygen and carbon dioxide in gas and blood of lungs: methods. J. appl. Physiol., 4, 102.

Rosenberg, E., and Forster, R. E. (1960). Changes in diffusing capacity of isolated cat lungs with blood pressure and flow. J. appl. Physiol., 15, 883.

Roughton, F. J. W., and Forster, R. E. (1957). Relative importance of diffusion and chemical reaction rates in determining rate of exchange of gases in the human lung, with special reference to true diffusing capacity of pulmonary membrane and volume of blood in the lung capillaries. J. appl. Physiol., 11, 290.

Schulz, H. (1962). Some remarks on the sub-microscopic anatomy and pathology of the blood-air pathway in the lung. In Ciba Foundation Symposium on Pulmonary Structure and Function, ed. A. V. S. de Reuck and M. O'Connor, p. 205. Churchill, London.

Scott, R. C. (1954). Pulmonary function in mitral stenosis: a review of current concepts. Ann. intern. Med., 41, 980.

Siösteen, S. M., and Sjöstrand, T. (1951). A method for determination of low concentrations of carbon monoxide in the blood and the relation between the CO-concentration in the blood and that in the alveolar air. Acta physiol. scand., 22, 129.

Sirs, J. A. (1963). Influence of metabolism on uptake of $\mathrm{CO}$ and $\mathrm{O}_{2}$ by hemoglobin in erythrocytes. J. appl. Physiol., 18, 175.

Staub, N. C. (1963). Alveolar-arterial oxygen tension gradient due to diffusion. J. appl. Physiol., $18,673$.

, Bishop, J. M., and Forster, R. E. (1961). Velocity of $\mathrm{O}_{2}$ uptake by human red blood cells. J. appl. Physiol., 16, 511 .

Stein, M., Kimbel, P., and Johnson, R. L. (1961). Pulmonary function in hyperthyroidism. J. clin. Invest., 40, 348.

Thews, G., and Niesel, W (1959). Zur Theorie der Sauerstoffdiffusion im Erythrocyten. Pflügers Arch. ges. Physiol., 268, 318.

Williams, M. H. (1953). Pulmonary function studies in mitral stenosis before and after commissurotomy. J. clin. Invest., 32, 1094. 